\title{
Artikel
}

\section{Het verschoningsrecht van de geestelijke}

\author{
Prof. mr. H.J.B. Sackers*
}

\section{Inleiding}

Ze worden het 'klassieke kwartet geheimhouders' genoemd, de advocaat, de notaris, de geneeskundige en de geestelijke. Ook die laatste, de geestelijke, mag vanwege zijn hoedanigheid als getuige zwijgen. Maar, wie is die geestelijke? En waarom is de geestelijke uit hoofde van zijn stand, beroep of ambt tot geheimhouding verplicht?

In deze bijdrage wordt het verschoningsrecht van de geestelijke aan een nadere beschouwing onderworpen. Opmerkelijk is dat, zoveel als er is geschreven over het verschoningsrecht van de eerste drie klassieke geheimhouders, zo weinig bekend is over de strafprocessuele rol van de laatste. ${ }^{1}$ De meeste handboeken beschrijven vooral de inhoudelijke kant van de vertrouwensberoepen, dikwijls mede met het oog op de mogelijke acceptatie van 'nieuwe' of 'afgeleide' geheimhouders, zoals registeraccounts en journalisten. Een enkele keer wordt verwezen naar de fiscale geheimhouders genoemd in artikel 53a AWR, maar ook daarin ontbreekt een nadere

Prof. mr. H.J.B. Sackers is hoogleraar bestuurlijk sanctierecht aan de Radboud Universiteit.

1. Uitzonderingen zijn: A.P.H. Meijers, 'De Geestelijke', in: F.A.W. Bannier e.a., Beroepsgeheim en verschoningsrecht. Handboek voor de advocaat, medische hulpverlener, notaris en geestelijke, Den Haag, 2008; J.J.I. Verburg, Het verschoningsrecht van getuigen in strafzaken, Groningen, 1975; J.B.M. Vrancken, Het professionele (functionele) verschoningsrecht, preadvies NJV, Zwolle, 1986, Daarentegen laat bijvoorbeeld Wisselink de geestelijke links liggen, M.A. Wisselink, Beroepsgeheim, ambtsgeheim en verschoningsrecht, Deventer, 1997. duiding van de geestelijke. ${ }^{2}$ Een verklaring voor de geringe belangstelling voor de geestelijke verschoningsgerechtigde kan worden gevonden in de zeer beperkte betekenis daarvan in de praktijk, echter zeker ook in de veranderde rol van de geestelijkheid in de hedendaagse samenleving. Juist dit laatste rechtvaardigt aan de verschoningsgerechtigde geestelijke aandacht te schenken en deze geheimhouder niet (langer) stiefmoederlijk te behandelen.

\section{Wetsgeschiedenis}

Onderzoek naar de vraag hoe de geestelijke aan zijn status als geheimhouder is gekomen levert een teleurstellend resultaat op. Weliswaar kende men in de versie van het Wetboek van Strafvordering uit 1838 al een professioneel verschoningsrecht, maar daarin werd de geestelijke niet afzonderlijk genoemd. Men volstond slechts met te verwijzen naar het Ontwerp Burgerlijk Wetboek van 1816 , waarin (voor zover hier relevant) stond dat geheimhouding gold 'voor alle kerkelijke personen, aan welken ter voldoening aan de stellige verpligtingen, bij een godsdienstig genootschap erkend, de wetenschap van eenige zaken is toevertrouwd'. ${ }^{3}$ Deze ontwerpbepaling heeft later model gestaan voor de (eerste versie) van het huidige artikel $218 \mathrm{~Sv}$, waarin met het begrip 'stand' op de kring van de geestelijkheid werd gedoeld. ${ }^{4}$ Daarbij

2. J.M. Reijntjes, Minckenhof's Nederlandse Strafvordering, Deventer, 2009 , p. 270. Art. 53a AWR luidt: 'Voor een weigering om te voldoen aan de verplichtingen ten behoeve van de belastingheffing van derden kunnen alleen bekleders van een geestelijk ambt, notarissen, advocaten, artsen en apothekers zich beroepen op de omstandigheid, dat zij uit hoofde van hun stand, ambt of beroep tot geheimhouding verplicht zijn.' Vergelijk ook art. 165 lid 2 onder b Rv.

3. T.N.B.H. Spronken \& F.J. Fernhout, commentaar op art. 218 Sv, in: A.I. Melai, Het Wetboek van Strafvordering, voortgezet door M.S. Groenhuijsen e.a. (red.), Deventer, (losbl.), (supl. 136, 2003).

4. Verburg, (a.w.), p. 107 
zij direct aangetekend dat uit de schaars beschikbare bronnen kan worden afgeleid dat de toenmalige wetgever het oog uitsluitend en welhaast vanzelfsprekend lijkt te hebben gericht op de katholiek geestelijke. Over diens positie, en in het bijzonder over de verplichting van de overheid om het biechtgeheim te respecteren, is geen discussie geweest. Dit parlementaire stilzwijgen bevestigt de traditie die tot bescherming van het biechtgeheim dwong. ${ }^{5}$ Kennelijk was die bescherming zodanig evident dat ook de niet-katholieke politici het biechtgeheim stilzwijgend eerbiedigden.

De katholieke kerk ${ }^{6}$ kent sinds de vroege middeleeuwen het sacrament van de biecht. Dit houdt kort gezegd in dat de gelovige tegenover de priester zijn zonden belijdt, die hem daarna worden vergeven en waarbij (indien de aard van de zonden daartoe aanleiding geeft) aan de biechteling penitentie wordt opgelegd. De biecht wordt in beginsel in een afgezonderde ruimte gehoord. ${ }^{7}$ Het biechtgeheim is aldus onlosmakelijk verbonden met de geheimhoudingsplicht van de priester, welke plicht in het canoniek recht strak is gereguleerd, en bij schending zwaar wordt gesanctioneerd. "Al hetgeen de priester in de sacramentele belijdenis is toevertrouwd, valt onder het biechtgeheim en het biechtgeheim is absoluut.' Deze stelling getuigt van profaan respect voor het canonieke recht, maar dient ook ter bescherming van de privacy, omdat zoals Remmelink het uitdrukte 'de openbaring van het biechtgeheim voor betrokkenen bijzonder pijnlijk kan zijn'. ${ }^{10}$

Was de erkenning van de geestelijke in de politieke verhoudingen van de negentiende eeuw min of meer vanzelfsprekend, minder gold dat het antwoord op de vraag bij welke kwaliteit de geestelijke het prerogatief van geheimhouder bezat. Dit probleem werd veroorzaakt

5. T.J. Noyon, G.E. Langemeijer \& J. Remmelink, Het Wetboek van Strafrecht, voortgezet door J.W. Fokkens, E.J. Hofstee \& A.M. Machielse, Deventer, (losbl.), (hierna: NLR), aant. 3 bij art. 272 (supl.136, 2006); J.B.M. Vranken, Het professionele (functionele) verschoningsrecht, preadvies NJV, Zwolle,1986.

6. Ook in de oosters-orthodoxe kerken en oosters-katholieke kerken kent men een biecht. Volgens de protestantse opvatting belijdt men de zonden bij God zelf, maar het 'huisbezoek' van de dominee wordt in de reformatorische kerk wel met de biecht vergeleken (zie A.P.H. Meijers, 'De Geestelijke', (a.w.), p. 175). Een aantal protestante geloofsgemeenschappen, waaronder de evangelisch-lutherse kerk, de anglicaanse en presbyteriaanse kerk, kent een met de biecht vergelijkbare belijdenis.

7. Een 'openbare biecht' komt (in andere religies) wel voor, maar hetgeen daarin wordt 'opgebiecht' lijkt zich niet met het verschoningsrecht van de geestelijke te verhouden. In Rb. Den Haag 1 maart 2013 (Basebyazaak), ECLI:NL:RBDHA:2013:BZ4292, AA 2013/938, m.nt. Van Sliedrecht, kwam een biecht tijdens een gebedssessie aan de orde (echter zijdelings en door de rechtbank als niet ondersteund door andere bewijsmiddelen gepasseerd).

8. Uit het canoniek recht (Codex luris Canonici): 'De biechtvader die het biechtgeheim rechtstreeks schendt, loopt een excommunicatie van rechtswege op die aan de Apostolische Stoel voorbehouden is; hij die het slechts onrechtstreeks schendt, dient naar gelang van de ernst van het misdrijf gestraft te worden. Het biechtgeheim is onschendbaar; daarom is het de biechtvader ten strengste verboden met woorden of op welke andere wijze en om welke reden ook over de boeteling ook maar iets bekend te maken.' De ambtsdragers van de Protestantse Kerk in Nederland leggen een belofte tot geheimhouding af.

9. Ph.J. Huyser, Het ambtsgeheim van de zielzorger, Kampen, 1961 p. 184.

10. NLR, aant. 3 bij art. 272 (supl. 136, 2006). door artikel $272 \mathrm{Sr}$ (het verbod van schending van geheimen) dat spreekt over 'ambt' of 'beroep', terwijl artikel $218 \mathrm{~Sv}$ daaraan 'stand' toevoegt. Moet de hoedanigheid van een tot verschoning gerechtigde geestelijke zijn te kwalificeren als ambt, of is het een beroep? Voor de katholieken was dat eenvoudig: iedereen die tot het afnemen van de biecht bevoegd is, bekleedt het ambt van geestelijke en behoort daardoor tot de 'geestelijke stand'. In zoverre leek dit dus een academisch dispuut. Maar, in de gereformeerd-protestantse kerk kent men bijvoorbeeld de ouderling, een functionaris die een vertrouwelijke positie binnen de geloofsgemeenschap vervult, maar van wie niet kan worden gezegd dat hij dit als ambt of beroep uitoefent. In (oude) rechtspraak werd om die reden aan de ouderling wel het verschoningsrecht toegekend, maar bleek hij niet onder artikel $272 \mathrm{Sr}$ te vallen. Hetzelfde gold voor kerkenraadsleden en kerkrentmeesters, met die beperking dat zij daarmee niet zonder meer (gelijk de ouderling) ook verschoningsgerechtigd zijn. ${ }^{11}$ Voor de geestelijk raadsman van de humanisten is een middenweg gecreëerd: voor zover deze raadsman zijn werk beroepsmatig uitoefent, komt hem zowel verschoning toe als de plicht tot geheimhouding. ${ }^{12}$ Het lijkt ondertussen erop dat de discussie 'ambt-beroep' in de (schaarse) rechtspraak uit moderner tijden niet is teruggekeerd, en hooguit nog praktische betekenis heeft bij de vraag naar de toepasselijkheid van artikel $272 \mathrm{Sr}$. Dat veel zielzorgtaken inmiddels zijn overgenomen door ouderlingen, pastoraal en kerkelijk werkers en (andere) vrijwilligers, zal daarbij ongetwijfeld een rol hebben gespeeld. ${ }^{13}$

\section{Welke geestelijke is verschoningsgerechtigd?}

Een geestelijke is volgens de gangbare woordenboeken een persoon die tot een kerk behoort als bedienaar van een godsdienst. De vraag die zich opdringt is wie zich allemaal tot de verschoningsgerechtigde geestelijkheid mogen rekenen. Aanvankelijk, zo bleek hiervoor, is bepleit dat dit alleen de 'bedienaren' konden zijn van godsdiensten die een (vorm van) biechtgeheim kennen, zoals de rooms-, Grieks- en Russisch-katholieke kerk. Een dergelijke beperking is echter in de literatuur niet omarmd, omdat de vertrouwelijke behartiging van geestelijke zorg zich niet kan beperken tot het instituut van de biecht. ${ }^{14}$ Maar, dit standpunt leidde wel een nieuw debat in met als centrale vragen in welke andere situaties de katholiek geestelijke een verschoningsrecht toekomt, en welke andere dan de katholiek geestelijke soortgelijke vertrouwelijke zorg biedt. In wezen viel de beantwoording van beide vragen min of meer samen. Al snel was

11. Hof Den Haag 24 januari 1949, NJ 1950/135; Rb. Rotterdam 24 januari 1933, NJ 1933, p. 977. Zie voorts: Meijers, (a.w.), p. 185-186.

12. Verburg, (a.w.), p. 112.

13. Meijers, (a.w.), p. 186-187.

14. Verburg, (a.w.), p. 109-110. 
in de literatuur consensus dat de geheimhouding niet alleen het sacrament van de biecht betrof, maar ook andere vormen kon omvatten waarin de priester door een gelovige informatie werd meegedeeld die hem als geestelijke werd toevertrouwd. Tegelijk werd daarmee ook de weg geopend om een geestelijke van een andere godsdienst onder de vlag van artikel $218 \mathrm{~Sv}$ te brengen. Dat was nauwelijks problematisch, nu het religieuze tableau van de eerste helft van de vorige eeuw zich verder slechts beperkte tot de geestelijken van de protestantse en joodse kerk. ${ }^{15}$ Nadien wisselt dit beeld. In Kamerstukken is terug te vinden dat in het midden van de vorige eeuw ongeveer negentig kerkgenootschappen bij de overheid stonden geregistreerd. ${ }^{16}$ Daarvan was ongewis of al die genootschappen voorgangers hadden die met de vertrouwelijke taak van de priester, de dominee of de rabbijn ${ }^{17}$ waren te vergelijken. Schreef Verburg in 1975 nog in zijn dissertatie 'te dubiëren over anderen dan de R.K.-geestelijke en de predikant', ${ }^{18}$ langzamerhand won de opvatting dat ook aan anderen het verschoningrecht van de geestelijke toekomt, en dat de rechter dan per geval zal moeten beoordelen of de betrokkene zich uit hoofde van zijn ambt of beroep als geestelijke kan verschonen. Daarover schreef Verburg in 1985 dat de rechter hiermee een delicaat probleem op zijn bord heeft gekregen. Enerzijds is voor religiositeit een zeker respect verschuldigd, anderzijds betekent dit niet dat ieder die zich als geestelijk leidsman of -vrouw in het strafproces opwerpt daaraan een positie als verschoningsgerechtigde kan ontlenen. ${ }^{19}$ Verburg schreef dit, kort nadat het rapport Overheid en nieume religieuze bemegingen was uitgekomen, en de vraag naar de rechtspositie van de geestelijke niet langer meer kon worden beantwoord naar de normen van het christendom of het jodendom, maar (volgens de rapporteurs) tegen het licht was komen te staan van de imam, de voorganger van de pinkstergemeente, de geloofsleider van de jehova's, maar ook de zielzorgers behorende tot bewegingen zoals de Bhagwan, hare krisjna en de scientology church. $^{20}$ Aan een definitie van 'religie' waagt het rapport zich niet, vermoedelijk omdat de rapporteurs zich van het

15. Vergelijk de (nog niet ingetrokken) Zondagswet, die uitsluitend oog heeft voor (christelijke) godsdienstoefeningen op zondag en op christelijke feestdagen; vergelijk ook de Wet beëindiging financiële verhoudingen tussen Staat en Kerk, waarin alleen de (rooms-)katholieke, de protestantse en de joodse kerken als partij worden genoemd (Stb. 1983, 638).

16. Kamerstukken II, 1957-58, 3769, nr. 5a. In 1999 is een inventarisatie gemaakt van kerken en religieuze stromingen in Nederland. Er zijn ruim 800 kerken en religieuze stromingen in Nederland. Hieronder vallen eeuwenoude kerkgenootschappen, maar ook Afrikaanse geloofsgemeenschappen, zenbewegingen en satanskerken. Zie: A. van Wijk e.a., Het warme bad en de koude douche. Een onderzoek naar misstanden in nieuwe religieuze bewegingen en de toereikendheid van het instrumentarium voor recht en zorg, Den Haag, 2014.

17. Over de erkenning van een verschoningsrecht voor de rabbijn is geen rechtspraak, maar in de literatuur wordt deze geestelijke op een lijn gesteld met de priester en de dominee, zie Meijers, (a.w.), p. 172.

18. Verburg, (a.w.), p. 106 e.v. Verburg acht de imam, de ouderling en de humanistisch raadsman verschoningsgerechtigd.

19. J.J.I. Verburg, Het beroepsgeheim, Arnhem, 1985, p. 45.

20. Kamerstukken II, 1983-84, 16635. gevaar bewust waren daarmee terecht te komen in een mijnenveld (zoals De Hullu het ooit uitdrukte). ${ }^{21}$

In de literatuur is bij het zoeken naar een antwoord op de vraag wie allemaal tot de geestelijkheid mag worden gerekend, onder meer aansluiting gezocht bij hetgeen artikel $449 \mathrm{Sr}$ bepaalt. Artikel $449 \mathrm{Sr}$ behelst het verbod een kerkelijk huwelijk te sluiten voordat het burgerlijk huwelijk is voltrokken. De bepaling richt zich tot 'de bedienaar van de godsdienst'. Uit de wetsgeschiedenis blijkt niet veel meer dan dat de wetgever daarmee op 'door de kerk aangestelde geestelijken en hun helpers' heeft gedoeld. ${ }^{22}$ Als echter tevens naar artikel 1:68 BW en het daarachter liggende motief wordt gekeken, ${ }^{23}$ dan blijkt dat de wetgever beide bepalingen noodzakelijk achtte vanwege het te duchten gevaar 'van het meer en meer splitsen van gezindten en kerkgenootschappen en het oplossen daarvan in bijzondere verenigingen' ${ }^{24}$ Met deze formulering lijkt de wetgever dus oog te hebben gehad voor de steeds verdere diversificatie van geloofsgemeenschappen en de daarmee gepaard gaande diversiteit aan geestelijke leidslieden. Een soortgelijk argument kan worden ontleend aan het (in 2014 geschrapte) artikel 147 Sr. Dat artikel kende naast het verbod op godslastering, ook artikelleden die de bedienaren van de godsdienst, en voorwerpen aan de eredienst gewijd tegen beschimping beschermden. Die artikelleden waren echter van aanzienlijk oudere datum dan het in 1932 toegevoegde verbod op godslastering, dat de naam van de God van de christenen (en mogelijk ook die van de joden) beschermde, ${ }^{25}$ terwijl met de bedienaren en de eredienstvoorwerpen veeleer op godsdiensten in het algemeen is gedoeld en zeker niet alleen op de christelijke religie. ${ }^{26}$ Uit de wetsgeschiedenis van artikel $137 \mathrm{c} \mathrm{Sr}$ (ter zake religiediscriminatie) blijkt nog duidelijker dat de wetgever zeker niet alleen aan de christelijke of joodse godsdienst heeft gedacht, maar aan alle religies die het bestaan van een God, of van een bovennatuurlijke macht aanvaarden. ${ }^{27}$ In feite vallen alle gangbare religies onder de bescherming van het verbod op godsdienstdiscriminatie. Maar, ook de geloofsgenoten van minder gangbare religies, en religies waarin een opperwezen of bovennatuurlijke macht minder vanzelfsprekend is of centraal staat, zouden op de bescherming van artikel 137c Sr mogen rekenen. In zijn commentaar op het wetsartikel maant Remmelink (die in dit verband ook de

21. J. de Hullu, 'Strafrecht, religie en literatuur', AA 1984, p. 752.

22. E.J. de Roo, Godslastering. Rechtsvergelijkende studie over blasfemie en andere religiedelicten, Deventer, 1970, p. 94. Art. $449 \mathrm{Sr}$ is zonder veel commentaar overgenomen uit de Code Penal.

23. In art. 1:68 BW wordt gesproken over 'de bedienaar van de eredienst'.

24. Memorie van toelichting, aangehaald door Remmelink, NLR, aant. 1a bij art. 449 (supl. 108, 2000).

25. B.A.M. van Stokkom, H.J.B. Sackers \& J.-P. Wils, Godslastering, discriminerende uitingen wegens godsdienst en haatuitingen, Den Haag, 2007, p. 96.

26. P.H.P.H.M.C. van Kempen, 'Religie in het Wetboek van Strafrecht', in: H. Broeksteeg \& A. Terlouw (red.), Overheid, recht en religie, Deventer, 2011, p. 169.

27. NLR, aant. 4 bij artikel 137c Sr; J.M. ten Voorde (T\&C Strafrecht, Deventer, 2016), aant. 9 bij art. 137c Sr; H.J.B. Sackers, 'De wonderlijke geschiedenis van art. 137c Sr', in: A. Elian e.a. (red.), Mag ik dit zeggen?, Den Haag, 2011, p. 309-328. 
scientology kerk ${ }^{28}$ noemt) in deze zin zelfs tot voorzichtigheid bij het al te vlug uitsluiten van religieuze bewegingen, 'wil men zich niet zelf het verwijt van discriminatie op de hals halen'. ${ }^{29}$

Dit leidt tot de volgende tussenconclusie. Hoewel de beeldvorming bij de aanvaarding van het verschoningsrecht van de geestelijke voornamelijk lijkt te zijn gekleurd door het biechtgeheim van de katholiek geestelijke (hetgeen op grond van de langdurige en dominante positie van de confessionele partijen in de Kamers goed verklaarbaar is), zijn er geen aanwijzingen dat de wetgever (gelet op het oude artikel 147 lid 2 en $3 \mathrm{Sr}$, en op de artikelen $137 \mathrm{c} \mathrm{Sr}$ en $449 \mathrm{Sr}$ ) het verschoningsrecht heeft willen beperken tot de bedienaren van de christelijke en joodse godsdienst. Of daaruit kan volgen dat het aantal gezindten met voorgangers die zich moeten kunnen verschonen onbegrensd is, valt echter sterk te betwijfelen.

\section{De geestelijk verzorger}

In dit verband is het interessant een uitstapje te maken naar het penitentiaire recht. In de Penitentiaire beginselenwet komt de term 'geestelijke verzorger' voor, iemand die namens de directeur van de penitentiaire inrichting verantwoordelijk is voor het geestelijke welzijn van die gedetineerden die pastorale zorg behoeven. Uit welke religies de geestelijke verzorging wordt aangeboden is nader uitgewerkt in artikel 24 van de Penitentiaire maatregel. Daarin wordt gesproken over geestelijk verzorgers van verschillende godsdiensten, 'doch in elk geval van protestantse en rooms-katholieke gezindte en geestelijke verzorgers behorend tot het humanistisch verbond'. In een nadere regeling heeft de minister daaronder mede verstaan 'de verzorgers van een overige stroming', te weten de islamitische, hindoeistische en boeddhistische gezindte. ${ }^{30}$ Opmerkelijk is dat de minister zelf de protestantse, rooms-katholieke en humanistische verzorgers benoemt (zij het op voordracht van de 'hoofdgeestelijke'), ${ }^{31}$ terwijl het aan de directeur van de penitentiaire inrichtingen wordt overgelaten of hij geestelijke verzorgers van andere gezindten aan zijn inrichting wil verbinden. In veel gevallen zijn door de directeuren (soennitische) imams aangetrokken.

Een enkele keer kan uit de penitentiaire beklagrechtspraak worden afgeleid dat zich geestelijke verzorgers aandienen, waarmee de gevangenisdirecteur moeite

28. Idem A.L.J. Janssens \& A.J. Nieuwenhuis, Uitingsdelicten, Deventer, 2007, p. 152. In de daaropvolgende druk noemen zij de scientology church niet meer (2011, p. 203).

29. NLR, aant. 4 bij art. 137c Sr. Het gaat hier om de bespreking van het materiele strafrecht.

30. Ook het Ministerie van Defensie (Diensten Geestelijke Verzorging) kent geestelijke verzorgers. Deze geestelijk verzorgers (aalmoezeniers, predikanten, raadslieden, rabbijnen, pandits en imams) werken bij de krijgsmacht namens een zendende instantie. Zij handelen vanuit een katholieke, protestantse, humanistische, joodse, hindoe of islamitische traditie, opleiding en vorming.

31. Bij het ministerie zijn een hoofdpredikant, een hoofdaalmoezenier en een hoofd humanistisch geestelijke verzorging aangesteld, art. 25 Penitentiaire maatregel. heeft. Zo besloot de directeur van PI Vught een gedetineerde geen toestemming te geven voor een gesprek zonder toezicht met een door hem gewenst geestelijk verzorger. Volgens de gedetineerde bestond bij de directie twijfel over de aard van zijn geloofsgemeenschap. Hoewel die gemeenschap in de uitspraak (slechts) als 'de Orde' wordt omschreven, kan uit de gegevens in de uitspraak worden afgeleid dat het hier om het 'Kerkgenootschap Orde der 'Transformanten' ging, waarvan de voorganger ('een gewijd theologe') wordt aangeduid als doctore. De gedetineerde diende een klacht in, maar aan een inhoudelijke beoordeling van de stelling van de klager is de beklagrechter (in het kader van deze bijdrage: helaas) niet toegekomen. ${ }^{32}$ In beroep stelde de beroepscommissie RSJ vast dat de geestelijke verzorger van de Orde niet tot de geestelijke verzorgers van de inrichting behoorde en derhalve was aangewezen op de reguliere bezoekregeling, inclusief toezicht. ${ }^{33}$

$\mathrm{Na}$ dit uitstapje, en op grond van het daaraan voorafgaande, kan de eerder getrokken tussenconclusie worden bevestigd. Vastgesteld kan worden dat tot de geestelijke verschoningsgerechtigde in ieder geval de personen die behoren tot de geestelijkheid van de wereldgodsdiensten kunnen worden gerekend. Ook voorgangers van andere geloofsgemeenschappen kunnen de status van verschoningsgerechtigde krijgen. Toch blijft nog een vraag naar de begrenzing open: hoe kan bij een zo belangwekkend recht als het verschoningsrecht het spreekwoordelijke kaf van het koren worden gescheiden? Hieronder zal nader worden ingegaan op een voorwaarde die zich in recentere rechtspraak lijkt af te tekenen, inhoudende dat het om bedienaren moet gaan van een serieus te nemen godsdienst.

\section{Bedienaar van een serieus te nemen godsdienst?}

De uit spaarzame jurisprudentie bijeengesprokkelde criteria leveren het volgende op. Het verschoningsrecht kan met kans op succes worden geclaimd door een persoon aan wie bij uitstek de geestelijke zorg van een min of meer georganiseerde geloofsgemeenschap is toevertrouwd, aan wie uit hoofde van die functie vertrouwelijke informatie is gegeven, en (bepaald het lastigste), die afkomstig is uit een geloofsgemeenschap die 'serieus' te nemen is.

Of de hiervoor genoemde Orde der Transformanten serieus te nemen is, bleef in het midden. Maar, een voorbeeld van een kerkgenootschap waarvan in rechte is vastgesteld dat het een serieus te nemen geloofsgemeenschap is, is de Santo Daime-kerk. Dit geloof is rond

32. Opmerkelijk is dat dit kerkgenootschap op haar website melding maakt van 'ophef' over de organisatie. 'Ons kerkgenootschap zag zich geconfronteerd met verdachtmakingen, valse beschuldigingen. Het $\mathrm{OM}$ en rechters hebben echter meermalen duidelijk gesteld dat de Orde niet verdacht is van enig strafbaar feit', www.ordedertransformanten.nl/ ophef, geraadpleegd op 11 maart 2017

33. Beroepscommissie RSJ 15 juli 1916, 15/4173/GA en 16/484/GA. 
1920 in Brazilië ontstaan, waarbij Indiaanse en Afrikaanse invloeden zijn samengesmolten met christelijke waarden en denkbeelden. Nieuwe rituelen zijn toegevoegd aan oude gebruiken, zoals het tijdens de eredienst drinken van ayahuasca-thee. $\mathrm{Nu}$ bevat die thee de stof DMT, een op de lijsten behorende bij de Opiumwet voorkomende stof, die de geloofsgenoten met enige regelmaat in conflict met het Openbaar Ministerie brengt. ${ }^{34}$ Niettegenstaande dit laatste (dat steevast tot een ontslag van alle rechtsvervolging leidt), worden de padrinho's of mestres als voorgangers van deze kerk erkend en zij zouden met succes een beroep op het verschoningsrecht kunnen doen. Serieus te nemen zijn bijvoorbeeld ook de 'zevendedagsbaptisten' en het 'Kerkgenootschap der zevendedagsadventisten', al is dit niet met zoveel woorden in een rechterlijke uitspraak vastgesteld. Al minder vanzelfsprekend geldt dit de Jehovah's getuigen, die zich geroepen hebben gevoeld zich op hun website nadrukkelijk te distantiëren van beweringen dat zij in plaats van een serieuze geloofsgemeenschap een sekteachtig karakter hebben. ${ }^{35}$ Ook de 'Noorse broeders' (officieel genaamd de Christelijke Gemeente Nederland, een onderdeel van de orthodox-christelijke Brunstad Christian Church) proberen zich te ontdoen van het etiket sekte, nadat zij in 2016 in de media in verband werden gebracht met vermogenscriminaliteit rondom een van de voormannen van deze geloofsgemeenschap, en eerder een waas van mogelijke verstrengeling van kerkelijke en commerciële belangen door voormannen van de gemeenschap was ontstaan. ${ }^{36}$

Twijfelachtig is zeker de status van de al eerdergenoemde scientology church. Zonder hier verder in (theologische) details te treden, kan deze 'kerk' op zijn minst genomen controversieel worden genoemd. Ze kent zowel oprecht gelovige volgelingen van oprichter Hubbard, als critici die deze kerk als een regelrechte sekte beschouwen en haar zelfs van criminele activiteiten beschuldigen. ${ }^{37}$ In Duitsland, België en Frankrijk zijn verscheidene procedures (wegens onder meer de beschuldiging van fraude) tegen de scientology church gevoerd. In de Verenigde Staten en in het Verenigd Koninkrijk werd zij echter als serieuze geloofsgemeenschap erkend, terwijl in Nederland haar de zogenoemde anbi-status $^{38}$ werd ontnomen, omdat deze kerk geen

34. HR 9 januari 2007, ECLI:NL:HR:2007:AZ2497, AB 2007/181, m.nt. Groen en Vermeulen, NJCM-bulletin 2007, p. 458, m.nt. Sackers; Hof Amsterdam 24 februari 2012, LJN BV6888; Rb. Noord-Holland 8 september 2016, ECLI:NL:RBNHO:2016:7555.

35. 'Nee, Jehovah's Getuigen zijn geen sekte. We zijn christenen die moeite doen om het voorbeeld van Jezus Christus te volgen en naar zijn leer te leven'; www.jw.org/nl/jehovas-getuigen (geraadpleegd 11 maart 2017).

36. J. Dohmen, NRC 18 maart 2016. Overigens verloor een stichting van de Noorse Broeders met terugwerkende kracht de anbi-status (zie voetnoot 39).

37. A. van Wijk e.a., (a.w.). Zeer kritisch over de scientology church was Gerrit Komrij, De stankbel van de Nieuwezijds; contra Scientology, Amsterdam, 1979.

38. Een fiscale status van een algemeen nut beogende instelling. De status heeft enkele fiscale voordelen tot gevolg. Zie: T. van Kooten, 'Kerk en fiscus: de zilveren koorde te nauw aangehaald?', in: H. Broeksteeg \& A. Terlouw (red.), Overheid, recht en religie, Deventer, 2011, p. 81-88. instelling is die uitsluitend activiteiten verricht van kerkelijke of levensbeschouwelijke aard. ${ }^{39}$

Twijfels gelden ook de beweging die zich de 'Kerk van het Vliegend Spaghettimonster' noemt, recentelijk in het nieuws vanwege de claim van de aanhangers van dit zogenoemde pastafarisme om op paspoort of rijbewijs te mogen worden afgebeeld met een vergiet als hoofddeksel. In de procedures die deze kerk voerde zag de rechter zich voor de vraag gesteld of deze kerk serieus te nemen is. De rechter verwijst daarbij naar een uitspraak van het Europees Hof (die overigens vooral ging over het dragen van religieuze voorwerpen op de werkplek ${ }^{40}$ en overwoog dat, om te kunnen worden aangemerkt als een serieus te nemen religie, naast enig samenwerkingsverband en/of enige samenhang tussen een groep personen, ${ }^{41}$ de gezamenlijk uitgedragen visie een zekere overtuigingskracht, ernst en gewicht moet hebben. Daarbij werd onderzocht of de leer van deze kerk getuigt van begrijpelijkheid, samenhang en importantie. Hoewel de rechter niet zonder meer uitsloot dat de in deze kerk gehanteerde vorm van satire een vorm van een geloof of levensbeschouwing kan zijn, oordeelde hij dat de kerkleer niet getuigt van voldoende serieusheid. Het pastafarisme mist dit en kan (met betrekking tot de uitvoeringsregelingen inzake de paspoort- of rijbewijsfoto) niet worden aangemerkt als een godsdienst of levensbeschouwing. ${ }^{42}$ Dit neemt niet weg, zo oordeelde de rechtbank, dat in meer algemene zin het pastafarisme in elk geval een in de maatschappij aanwezige levensbeschouwende stroming is. Met deze laatste overweging lijkt de rechter de deur naar een mogelijk verschoningsrecht van de eventuele leidslieden van deze beweging niet helemaal te hebben gesloten. ${ }^{43}$

\section{Sektes?}

De status van een serieus te nemen geloofsgemeenschap past niet voor sektes. Maar, daarbij behoort direct een relativerende opmerking. Bepaald lastig is te definiëren waarin een sekte zich van een geloofsgemeenschap onderscheidt, nu een sekte zich dikwijls (ook) kenmerkt door een bepaalde vorm van (geloofs)overtuiging. Het verschil zit vooral in het feit dat een sekte in het spraak-

39. Daarvoor waren wel enige procedures nodig: Hof Amsterdam 17 oktober 2013, ECLI:NL:GHAMS:2013:3338, V-N 2014/6.1.2, HR 12 december 2014, ECLI:NL:HR:2014:3565, BNB 2015/59, m.nt. Boer, Hof Den Haag 21 oktober 2015, ECLI:NL:GHDHA:2015:2875, V-N 2015/65.1.2, HR 25 november 2016, ECLI:NL:HR:2016:2665, V-N 2016/62.7

40. EHRM 15 januari 2013 (Eweida vs. Verenigd Koninkrijk), EHRC 2013/67, m.nt. Gerards. Het Hof ziet als voorwaarde voor het aanmerken van opvattingen of meningen als een geloof ('religion') of levensovertuiging ('belief') dat die opvattingen 'attain a certain level of cogency, seriousness, cohesion and importance'.

41. Het moet gaan om een reëel personensubstraat dat zich heeft aangesloten bij een kerkgenootschap, Hof Amsterdam 8 februari 2017 , ECL:NL:GHAMS:2017:410.

42. Rb. Gelderland 17 januari 2017, ECLI:NL:RBGEL:2017:275, Rb. OostBrabant 15 februari 2017, ECLI:NL:RBOBR:2017:762.

43. Rb. Noord-Nederland 28 juli 2016, ECLI:NL:RBNNE:2016:3626. 
gebruik een pejoratieve connotatie heeft. ${ }^{44}$ In de oorspronkelijke betekenis is een sekte een zich ten opzichte van de gevestigde geloofsgemeenschap kritisch opstellende en soms daarvan afgescheiden religieuze gemeenschap, terwijl het spraakgebruik ziet op een nauwelijks georganiseerde en weinig stabiele (religieuze) gemeenschap, met aan het hoofd een charismatisch, maar soms (figuurlijk) onnavolgbaar leider. De beeldvorming over sektes als dubieuze organisaties wordt gevoed door de berichtgeving over misstanden. Daarbij gaat het om machtsmisbruik, seksueel misbruik, hersenspoeling, indoctrinatie en massale zelfmoord, zoals bij 'Jim Jones' People's Temple' in Guyana, de Amerikaanse beweging 'Children of God', of de volgelingen van David Koresh in Waco (Texas). In ieder geval is duidelijk dat bij sektes een schimmig gebied wordt betreden. Tegen de volgelingen van Bhagwan (Shree Rajneesh) werd aanvankelijk, en vooral vanwege hun oranje kleding, wat vreemd angekeken, maar zij werden uiteindelijk wel als spiritueel genootschap gezien. Maar aan 'Lou de Palingboer', die in de vorige eeuw een religieuze beweging vormde, is de status van sekteleider en bepaald niet die van geestelijk leider toegekend. ${ }^{45}$ Nog evidenter was de kwalificatie van de leidinggevenden van de 'Kloosterorde der zusters van Walburga' die (tevergeefs) bij de rechter aanklopten om gevrijwaard te blijven van een al te bemoeizuchtige overheid. Volgens het hof waren de activiteiten in de kerk niet te onderscheiden van activiteiten die in een gewone seksinrichting plaatsvinden en waren de als zusters aangeduide vrouwen gespeend van enige religieuze ervaring. ${ }^{46}$ Hetzelfde lot viel de vertegenwoordigers van de satanskerk ten deel, nadat ze (evenmin met succes) dezelfde fiscale privileges wilde afdwingen die (erkende) geloofsgemeenschappen (wel) genoten. Ook hier werden de kerkdiensten door de Hoge Raad eerder gezien als de exploitatie van hardpornoshows, van een seksbioscoop en van seksueel-erotische optredens, dan als religieuze activiteiten. De leidinggevenden werd de status van geestelijke onthouden en de satanskerk werd belastingplichtig geoordeeld. ${ }^{47}$ Voorbeelden van zaken waarin voorgangers van sekteachtige organisaties het verschoningsrecht als geestelijke claimden, zijn niet voorhanden.

\section{Schaarse rechtspraak}

Rechtspraak waarin de geestelijkheid figureert is ruim voorhanden, helaas in overgrote meerderheid met een geestelijke als verdachte. Dat het merendeel van die zaken zedendelicten betreft, zal niet verbazen, maar ook

44. Teneinde de negatieve klank van het woord sekte te vermijden, pleegt men ook wel de term 'nieuwe religieuze bewegingen' te hanteren.

45. W. Zaal, Gods onkruid: Nederlandse sekten en messiassen, Soesterberg, 2004.

46. HR 31 oktober 1986, NJ 1987/173, m.nt. Van Veen (Zuster van Walburga).

47. HR 22 maart 1989, BNB 1990/161 (Kerk van Satan), uitgebreid besproken door I.U. Tappeiner, 'Belastingen en godsdienst', AA 2004, p. 588-589. vermogensdelicten (zoals verduistering) komen voor. Bekend zijn verder ook de zaken waarin een dominee en een imam zich voor een uitingsdelict moesten verantwoorden. ${ }^{48}$ Het spreekt voor zich dat het (professionele) verschoningsrecht niet speelt bij de verdachte geestelijke.

Iets genuanceerder is wellicht het optreden van een geestelijke als deskundige. Hoewel het niet voor de hand ligt dat een deskundige zich vanwege zijn ambt of beroep op verschoning zal beroepen, laat de Koolviszaak (een grootschalig onderzoek naar mensenhandel) zien tot welke complicaties de inzet van een dominee als ervaringsdeskundige in het opsporingsonderzoek kan leiden. $^{49}$

Omgekeerd evenredig zijn er nauwelijks uitspraken over het verschoningsrecht van de geestelijke. Te noemen zijn slechts de volgende uitspraken. Een heel oud, maar nog immer lezenswaardig arrest dateert uit 1857. Voor het Provinciaal Geregtshof van Gelderland was een pastoor opgeroepen als getuige. Ter zitting beriep hij zich voorwaardelijk op zijn verschoningsrecht. Kort samengevat wilde de pastoor slechts spreken indien de verdachte hem daarvoor de toestemming gaf. Dat kon niet, oordeelde het hof. Het belang dat de wetgever aan het verschoningsrecht van een rooms-katholiek priester hecht, kan door de toestemming niet terzijde worden geschoven. ${ }^{50}$ Wellicht dat dit argument in de negentiende eeuw nog als valide gold, naar de huidige maatstaven komt dit oordeel onjuist voor. Van een andersoortige visie getuigt een beschikking van de Rechtbank Groningen uit 1940. Een gereformeerd dominee moest getuigen over het voorgevallene tijdens een huisbezoek dat hij tezamen met een jongeman had afgelegd bij een zwanger meisje en haar grootmoeder. De jongeman zou volgens geruchten de 'gedoodverfde vader' van het ongeboren kind zijn. De gepubliceerde uitspraak laat in het midden in welk verband dit tot het strafrecht staat, vaststaat dat de dominee met een beroep op zijn verschoningsrecht de rechter weigerde informatie over de inhoud van het huisbezoek te verschaffen. Het beroep van de dominee werd echter met een wat cryptische overweging afgewezen, omdat 'de dominee aanwezig was bij een andere gelegenheid, ook al was hij daarbij tegenwoordig als predikant'. ${ }^{51}$ Ook de visie van deze rechtbank keert niet terug in de modernere rechtspraak. De kern van het verschoningsrecht van de geestelijke ligt in de vertrouwelijkheid van de zielzorg, en is niet afhankelijk van de gebouwelijke situatie. ${ }^{52}$

Van de meer antieke rechtspraak naar de hedendaagse, brengt een vonnis van de Rechtbank Maastricht uit 2009 voor het voetlicht. De verdachte, een penningmeester van een katholiek dekenaat en tevens bewindvoerder van 
een persoon, werd in deze zaak valsheid in geschrifte verweten. Bij de politie was het vermoeden ontstaan dat de onderbewindgestelde schenkingen aan de kerk had gedaan die door de bewindvoerder ofwel zonder toestemming van de kantonrechter waren aangewend, of door hem in eigen zak waren gestoken. Uit tapverslagen kon worden vastgesteld dat de verdachte op enig moment over deze kwestie een gesprek heeft gevoerd met de deken (een priester). De rechtbank stelde aan de inhoud van het gesprek vast dat dit gesprek onder de geheimhouding viel en mitsdien had moeten worden vernietigd. Het leidde evenwel niet tot de niet-ontvankelijkheid van het Openbaar Ministerie, omdat de inhoud van het gesprek door de rechtbank als 'zakelijk en niet-sturend voor het opsporingsonderzoek' werd geduid. Een ander in deze zaak gepresenteerd bewijsmiddel was een 'pastorale tip' die de verdachte aan een derde had gegeven. Omdat de verdachte geen geestelijke was, kon de inhoud van die tip ondanks het pastorale karakter (wat dat dan ook moge zijn) worden geaccepteerd. In dit vonnis heeft de rechtbank dus bij twee incidenten eerst beoordeeld of het om een geheimhouder gaat, dat vervolgens in één geval vastgesteld, maar daarna een beoordeling over de gespreksinhoud gegeven. ${ }^{53}$ Wat daarvan verder ook zij, het vonnis geeft (wellicht bij gebreke van een daartoe strekkend verweer) geen richting aan de vraag of, en zo ja, in welke mate hier het verschoningsrecht van de geestelijke in geding is geweest, al ligt de vergelijking met ten onrechte getapte gesprek-

\section{Beroept de geestelijke zich wel op verschoning?}

Bij het jurisprudentieonderzoek dat aan deze bijdrage ten grondslag lag, deed zich een opmerkelijkheid voor die de praktische betekenis van het verschoningsrecht van de geestelijke, in de praktijk toch al niet zo belangrijk, nog sterker doet relativeren. Die opmerkelijkheid bestond hierin dat geestelijken tenminste in een aantal gevallen waarin zij zich, objectief gezien, zouden mogen verschonen, van dit recht geen gebruik maakten. Zo verklaarde een dominee belastend over een verdachte die hem bij de kerkdienst vertrouwelijk had gevraagd aan het einde van de dienst te bidden voor een 'payback', hetwelk, naar de dominee begreep, niets minder dan het aftuigen inhield van een ander persoon waarmee de verdachte in onmin was geraakt. ${ }^{54}$ Ook in een andere zaak gaf een geestelijke een voor de verdachte belastende getuigenis. Hij verklaarde: 'Ik sprak [de verdachte] in de moskee bij het vrijdaggebed, hij zei tegen mij dat hij zijn vrouw ging vermoorden. ${ }^{55}$ Kennelijk werd deze bizarre opmerking niet gezien als een de geestelijke in diens hoedanigheid toevertrouwd zielenroersel. Ook in een

53. Rb. Maastricht 8 december 2009, ECLI:NL:RBMAA:2009:BK6853

54. Rb. Den Haag 20 oktober 2005, ECLI:NL:RBSGR:2005:AU4709.

55. Rb. Groningen 11 oktober 2010, ECLI:NL:RBGRO:2010:BO0132.

zedenzaak was een dominee tot getuigen bereid. Hij verklaarde gedetailleerd over de inhoud van een gevoerd telefoongesprek waarin hem vertrouwelijke details van het ten laste gelegde feit ter ore zijn gekomen, aan welke getuigenis de rechtbank 'bijzondere betekenis' voor het bewijs heeft gehecht. ${ }^{56}$

$\mathrm{Nu}$ kan het heel goed zijn dat in deze zaken de gevolgen van het handelen van de verdachten zo ernstig waren, dat de betreffende geestelijken de noodzaak tot het afleggen van een verklaring hoger hebben gewaardeerd dan een beroep op hun professionele verschoningsrecht. Indien deze aanname juist is, geeft dit aan dat geestelijken goed tot een waardering van het verschoningsrecht in staat zijn door daarop niet onder alle omstandigheden een beroep te doen. Het kan ook zijn dat de geestelijken de informatie niet van dien aard beschouwden dat zij daarover zouden moeten zwijgen. Ingewikkelder ligt een volgend voorbeeld, waarin een geestelijk verzorger in een gevangenis getuige was van een vechtpartij tussen gedetineerden, terwijl hij met de aanstichter een vertrouwensband had. Hij meldde het incident bij de gevangenisdirecteur, gaf daarbij enerzijds te kennen geen beroep te willen doen op zijn beroepsgeheim, maar verzocht anderzijds om 'buiten beeld te mogen blijven'. Om hieraan tegemoet te komen werd door de directeur voor een 'de auditu'-constructie gekozen, waarbij iemand anders de verklaring van de geestelijke in een officieel rapport opnam, echter zonder diens identiteit te onthullen. De keuze voor deze constructie werd vervolgens voorgelegd aan de beklagrechter, bij wie de vechtersbaas opkwam tegen de hem opgelegde sanctie, die prompt de geestelijke opriep ter zitting te verschijnen om nadere inlichtingen te verschaffen. Die gaf aan de oproep geen gevolg, waardoor beklag- en beroepsrechter uiteindelijk de feitelijke gang van zaken onvoldoende toetsbaar oordeelden. ${ }^{57}$

Doen geestelijke dan nauwelijks een beroep op het verschoningsrecht? Toch wel, maar het komt in de praktijk bijna niet voor dat een geestelijke wordt verzocht om te getuigen over zaken die hem (of haar) in die hoedanigheid zijn toevertrouwd. Een voorbeeld waarin een geestelijke zich nadrukkelijk op zijn verschoningsrecht beriep, is een bizar zedendelict waarvan een godsvruchtige $^{58}$ (katholieke) vrouw slachtoffer werd. Het merendeel van de (seksuele) handelingen vond plaats ofwel op bedevaartreizen naar Lourdes, ofwel speelde zich anderszins in een religieuze context af. Het was dan ook niet verwonderlijk dat deze strenggelovige vrouw op een gegeven moment te biecht ging en de priester alles over de grote zonde van 'seks voor het huwelijk en met een reeds gehuwde man' vertelde. Later herhaalde zij dit in een volgende biecht bij een andere priester. Die priester is daarna met de verdachte en het slachtoffer een

56. Rb. Overijssel 19 april 2016, ECLI:NL:RBOVE:2016:1332. In deze zaak is niet duidelijk in welke mate de getuigende dominee een vertrouwensrelatie met de verdachte had.

57. Beroepscommissie RSJ 16 oktober 2012 12/1567/GA.

58. Het inspelen op haar devotie en/of godvruchtigheid was als 'andere feitelijkheid' in de zin van art. $242 \mathrm{Sr}$ ten laste gelegd. Zie hierover uitgebreid de conclusie van de A-G (ECLI:NL:PHR:2013:415). 
gesprek aangegaan en gaf hun de opdracht 'ermee' te stoppen. De politie wist een van deze priesters te vinden, die verklaarde zich het slachtoffer nog goed te herinneren, maar tevens dat hij niets mocht verklaren over hetgeen hij wist. Inmiddels was de politie te weten gekomen dat ongeveer in dezelfde tijd ook de verdachte bij diezelfde priester had gebiecht. De verdachte weigerde over de inhoud daarvan iets te verklaren, zodat het de politie niet zinvol voorkwam de betreffende biechtvader opnieuw te benaderen. Ook al waren het Openbaar Ministerie en de verdediging het (met wisselende conclusie) eens over het feit dat het bewijs 'dun' was, noch bij de rechtbank, noch bij het hof is de positie van de verschoningsgerechtigde biechtvader(s) onderwerp van discussie geweest. ${ }^{59}$

\section{Conclusie}

Ter afronding van deze bijdrage kan worden vastgesteld dat het verschoningsrecht van de geestelijke voor zover die behoort tot een van de wereldgodsdiensten, nimmer voorwerp van discussie is geweest. Niet valt uit te sluiten dat dit mede kan worden verklaard door de geringe praktische betekenis. Aangenomen moet worden dat het maatschappelijk belang van het respecteren van de geheimhouding nog steeds zwaarder weegt dan het belang van strafvordering. ${ }^{60}$ Daaraan doet niet af dat het aantal mensen dat zich tot een bepaalde geloofsovertuiging aangetrokken voelt sedert decennia steeds verder afneemt, evenmin dat de nog immer woekerende misbruikschandalen in (met name) de katholieke kerk stemmen deden opgaan het katholieke biechtgeheim niet langer te accepteren, nu de indruk was ontstaan dat de biechtstoel een plaats is geworden waar een verdachte ogenschijnlijk mentaal asiel dacht te vinden.

Wat een nieuwe dimensie aan het verschoningsrecht heeft toegevoegd is de vraag naar de status van 'nieuwe' geestelijken. Hoe de politie met zo een geestelijke als gewenst getuige omgaat, is niet bekend. Ook is geen zicht op de door de verdediging gewenste (geestelijke) getuigenissen, waarvan de zittingsrechter de noodzakelijkheid niet inzag of geen verdedigingsbelang wilde aannemen. Uit de weinige rechtspraak waarin wel een oordeel moest worden gegeven, vallen de volgende conclusies te trekken.

De rechter beoordeelt het verschoningsrecht (uiteraard) steeds in de context. Daarbij lijkt eerst de vraag aan de orde te komen of de religie serieus is te nemen. Die vraag wordt langs twee sporen onderzocht. Bij de geloofsgemeenschap dient sprake te zijn van enig samenwerkingsverband en/of enige samenhang tussen

59. HR 27 augustus 2013, ECLI:NL:HR:2013:494, NJ 2013/427.

60. Zie bijvoorbeeld A-G Fokkens in zijn conclusie voor HR 16 oktober 1990, NJ 1990/175, waarin hij het afluisteren van de biecht zo schandelijk noemt, dat geen twijfel eraan bestaat dat dit tot bewijsuitsluiting moet leiden. Titel 6.2 van het concept-wetsvoorstel tot vaststelling van Boek 1 van het nieuwe Wetboek van Strafvordering bevat ten aanzien van de verschoningsrechten geen wijzigingen. de groepsgenoten. De groepsgrootte lijkt daarbij niet van belang, al zal het duidelijk zijn dat men gedrieën geen geloofsgemeenschap kan vormen. ${ }^{61}$ Vervolgens beziet de rechter of deze gemeenschap in gezamenlijkheid een visie uitdraagt die een zekere overtuigingskracht, ernst en gewicht heeft. De rechter ontkomt hierbij niet geheel aan een beoordeling van het theologische kader waarin de geestelijke bepaalde informatie werd toevertrouwd. De tweede vraag is of degene die het verschoningsrecht claimt, ook als geestelijke, als voorman of leidsman kan worden aangemerkt. ${ }^{62}$ Die vraag is maar heel summier in de rechtspraak terug te vinden. Wat terug is te vinden, is dat wordt bezien welke taken en verplichtingen de geestelijke volgens zijn religie heeft, maar bijvoorbeeld niet of voor het zijn van geestelijk leidsman een opleiding is vereist. ${ }^{63}$ Dit laatste levert een merkwaardige ambivalentie op. In het penitentiaire recht stelt de regelgever kwaliteitseisen aan de 'geestelijk verzorger' (een universitaire titel in de theologie of voor de boeddhistische gezindte - een voordracht $)^{64}$, terwijl (ondanks het bestaan van een opleiding tot imam) voor de meeste islamitische stromingen niet noodzakelijk is dat de gebedsvoorganger een specifieke opleiding heeft genoten, los van de verschillende opvattingen over de rol en betekenis van de imam in het islamitische geloof. Hetzelfde beeld geven enkele andere religies te zien. Het zou verdedigbaar zijn dat voor de erkenning van het professionele verschoningsrecht, niet alleen aan de hoedanigheid van advocaat, arts of notaris, maar ook aan de geestelijke de voorwaarde van een zekere mate van gebleken competentie wordt gesteld. Alleen dan kan het verschoningsrecht voor de geestelijkheid in de toekomst nog steeds serieus worden genomen, en blijven charlatans daarvan (terecht) verstoken.

61. Verburg acht de grootte wel van belang en bepleit dat die 'enigszins omvangrijk' moet zijn, Verburg, (a.w.), p. 111

62. Of zoals Hazewinkel-Suringa het uitdrukte: de zielzorger moet gepatenteerd zijn, D. Hazewinkel-Suringa, De doolhof van het beroepsgeheim, Haarlem, 1959.

63. Ondanks het pleidooi daartoe van Verburg, in: Verburg (a.w.), p. 111.

64. Regeling functie-eisen geestelijk verzorgers overige stromingen, Stcrt. 2002, 108. 